Alisa Velaj - Arben P. Latifi

\title{
6 Poems
}

\section{Breath}

1

misty tulips

a mist of tulips

of tulips

of tulips

a morning spread like a dream

over rivers...

don't you wake up Atlas's son

don't

don't

let him sleep

with his head resting

on a pillow of tulips

2

white tulips

son's light

light

yellow tulips

son's sun

sun

red tulips 
red

red

father's sunset

like fire through backbone

fire

3

a mist of purple

over rivers

over rivers

the dreamy migrates anew

from tulip to tulip

purple in a bed of mist

purple

a sweet melody

of river

of fire

Assen, Netherlands

August 2018

\section{That blue tulip!}

That tulip hidden between two trunks

deep in the woods, deep in there,

dreams every instant

of sipping a little more dew.

Honey dew,

as the sun sets down at dusk... 
That blazing-body tulip,

that blue tulip!

Amsterdam, August 2018

\section{To You}

This season, you lull under a sky superior to mine;

the thin hoarfrost on trees is fog respiration only,

which shreds our landscapes in crystals of lethargic winters...

Wake up, for the nature's spirit is raving in feminine heat,

under guitar strums that grunt for love

and whisper no farewell to forget-me-not flowers...

Freeze like dusk in front of abrupt light,

in a land shivering of lonely tunes, under a sky

where the sun doesn't shine to merely show-off!

Freeze in the flames

slumbering lustily in the blood of spring embers,

freeze, and still show up on doorsteps

shiny like this sky, my handsome one!

\section{A Cat Like No Other...}

Latest media news:

"Billionaire Lagerfeld willed his whole estate to his cat, Choupette."

There is now a cat

with her fur much more expensive

than all of the ladies' fur coats in Broadway! 
A royal cat, whimsical and pampered,

that has folks wonder of the eventual male suitor

she'll drive mad to the point of committing suicide!

Our dearest little heiress, with her bluest eyes,

now outshines the enthusiastic ornithologist,

who lectures on and on about birds

to an audience of huge fans of stunning fowl photos,

feathers and chirps,

who claims absolute expertise on flying,

but knows nothing of children in Aleppo!

\section{Accursed...}

In the alpine Accursed Woodlands,

where time stands still,

breath stands no chance to breathe,

o traveler!

At the Blessed Bridge,

do not pin your hopes on the stone,

if waters first didn't bless your trip,

o Man!

\section{The Coolest Loser}

Blind eyes, sleepy,

across worldly winters -

eyes sunk into blooming abysses, my loser.

Please take a quick look at the sun by dawn, 
it's a lamp brighter than an eye's pupil...

O coolest loser, with three lanterns in hand,

no loony got enlightened under moonlight;

springtime wolves grow white-haired like men,

hunters, though, can hardly spot them out in snow!

\section{(c) (i) (9)}

Creative Commons Attribution-NonCommercial-NoDerivatives 4.0 International License 